UDC 91(477):338.48/2(075.8)

\title{
RELIGIOUS-PILGRIM TOURISM IN THE WEST OF UKRAINE: MAIN CENTRES AND SHRINES
}

\author{
Yuriy Zinko $^{1}$ (D), Marta Malska ${ }^{1}$ (D), Taras Hrynchyshyn ${ }^{2}$ (i) \\ ${ }^{1}$ Ivan Franko National University of Lviv, \\ P. Doroshenko St., 41, UA - 79007 Lviv, Ukraine, \\ e-mail: zinkoyuriy@gmail.com,malskym@ukr.net \\ ${ }^{2}$ Lviv Regional State Administration, \\ V. Vynnychenko St., 14, UA - 79008 Lviv, Ukraine, \\ e-mail:tarasiy4@gmail.com
}

This study analyzes the formation factors and major centres and shrines of pilgrimage and religious tourism in the Western region of Ukraine. The article presents structure of the religious space of 8 regions of Western Ukraine in the context of major Christian denominations. According to the latest statistics in the West of Ukraine, among the Christian denominations we can see dominance of believers and communities of the Ukrainian Greek-Catholic Church, the Orthodox Church of Ukraine, the Ukrainian Orthodox Church of the Moscow Patriarchate and the Roman Catholic Church.

The main pilgrimage centres that represent the Christian denominations of the region are characterized by attracting their faithful and at the same time serving as religious tourism centres for a wider range of people. These include, among others: Univ Lavra, Krekhiv and Hoshiv Monasteries, the Marian Spiritual Centre in Zarvanytsia (Greek-Catholic Church); Maniava Skete, St. George Monastery on the Cossack Graves (Orthodox Church of Ukraine); Pochayiv Lavra, Zymne and Mezhyrich Monasteries, Monasteries in Bukovyna and Transcarpathia (Orthodox Church of the Moscow Patriarchate). At the same time, the Roman Catholic Church is represented by sanctuaries: Basilica of the Assumption of the Blessed Virgin Mary in Lviv, churches in Stryi, Bilshivtsi, Chortkiv, Letychiv and other settlements. The annual number of visitors to these major centres is between 30 and 100 thousand people a year.

Regarding non-Christian religions, there are important shrines in the region for Hasidic pilgrims in Belz, Medzhybizh and other towns.

At the same time, a number of regional centres are important destinations. There are many temples in Lviv, Ivano-Frankivsk, Lutsk, Ternopil, which, given the presence of objects of religious worship and significant architectural appeal, perform both a pilgrimage and a religious-tourist function.

Religious shrines, which are primarily of natural origin, are often an important component of the pilgrimage-tourist movement in the West of Ukraine. These include the appearance of Virgin Mary, including individual hills or springs, as well as ancient cave monasteries. Numerous pilgrimage and travel agencies actively promote visits of believers and tourists to them.

Development of religious and pilgrimage centres is related to the development of service infrastructure, service complexes and a network of different types of accommodation. It may be recommended to organize more educational and scholarly events of ecumenical nature and meetings of faithful of different denominations in the well-known religious centres of the region.

Key words: pilgrimage, religious tourism, denominations, temple, shrine, pilgrimage centre, infrastructure.

(C) Zinko Yu., Malska M., Hrynchyshyn T., 2019

ठ Open Access (cc) BY публічної ліцензії Creative Commons "Із зазначенням авторства -4.0 міжнародна" 
During the last decade in Ukraine, especially in its western part, religious tourism has been actively developing. The investigation of this phenomenon is based on methodological, structural and territorial levels. Ukrainian researchers $[6,11,12]$ in the field of geography of religions and religious tourism have formulated basic notions and terms of these disciplines and methodical approaches to the study of structural, spatial and temporal aspects of sacral objects, religious confessions and religious trips and pilgrimages. These investigations consider religious tourism as a wider notion, while pilgrimage is treated as a specific form of religious tourism [6, 12]. There exists also a suggestion to use a generalized notion of religious and pilgrimage tourism $[1,3,6]$. A number of studies present major religious attractions (places of pilgrimage, religious and cultural centres) on national and regional levels. Newly founded pilgrimage centres and special publications (guidebooks, maps, web-pages) play an important role in the popularization of religious and pilgrimage tourism in the practical context.

Western Ukraine is characterized by different denominations and a wide spectrum of religious and pilgrimage places [11]. This region possesses the most important network of pilgrimage routes and religious tours. It is often considered as a model one for studying spatial aspects of the structure of religious objects and their visiting by pilgrims and tourists $[8,16]$.

Research of religious tourism in Ukraine does not consider humanistic approaches related to social, psychological and theological aspects. They are rather important for considering the motives of religious trips, formation of social relations and dialogues in the religious and pilgrimage centres [2]. The use of humanistic approaches in the studies of religious tourism on the multi-confessional territory of Western Ukraine allows fuller reproducing of conditions and consequences of religious and pilgrimage movement in the major religious centres and places.

Scope of the study of religious tourism. Study of religious tourism is already a significant tradition abroad [1, 3, 4] and is becoming relevant in Ukraine. The very concept of religious tourism can have a wide interpretation and include the pilgrimage movement $[6,12,23]$, and narrow, which deals with tourist travel to religious places [23]. A. Kovalchuk and others (2016) propose to distinguish in a cognitive sense two separate areas of study: pilgrimage and religious tourism [6]. Pilgrimage to the subject of the research means a trip undertaken by believers to visit religious sites while religious tourism is a tourist journey to the religious objects of studing $[6,23]$. Religious (sacred) objects, the tourist flow of worshippers and tourists, as well as the organizers of these trips are the main components in studies of religious tourism and pilgrimage.

A major achievement in conceptual and categorical terms in the field of geography of religions and religious tourism is the elucidation of the essence of the basic concepts of "worship", "religious shrines", "the pilgrimage to Holy sites and objects", the pilgrim and the religious tourist centres $[6,23]$ and concepts related to geospatial structure - the "sacred space", "religious space", "religious space" [11]. Important for understanding religious and pilgrimage tourism are general theological studies $[2,20]$ and geographic studios with respect to the major religions $[6,12]$, or separate denominations in Ukraine $[6,19,32]$. In the applied aspect, the assessment of religious-pilgrimage tourism for the economic and social development of territories, as well as organizing tours of relevant areas are important [18].

The regional aspects and factors of the formation of the spatial organization of religious denominations for the western regions of Ukraine have been comprehensively analyzed in the studies of I. Kostashchuk (2018) [11]. For certain regions of the area - Lviv, Volyn, Chernivtsi. Ternopil - the religious-pilgrim resources and centres of religious tourism, as well as their organizational support $[6-8,10,11,19]$ are covered in detail. 
The presented study focuses on the religious and tourist resources of the western region of Ukraine. These include religious-tourist and pilgrimage centres and religious shrines of anthropogenic and natural-anthropogenic origin. In the study of religious pilgrimage centres and shrines, the main focus was on the complex characteristics of the religious centre or shrine with the complementary nature of their pilgrimage and tourist use. Religious and pilgrimage tourism was considered in the context of religious sites of different denominations represented in the region. The statistics on the number of churches and religious organizations [21] were used.

Religious-denominational space of the west of Ukraine. Western Ukraine is administratively represented by 8 regions - Lviv, Ivano-Frankivsk, Ternopil, Zakarpattia (Transcarpathia), Chernivtsi, Khmelnytskyi, Volyn and Rivne. Each of the regions has its own structure of Christian denominations.

It is important to notice, that since early $1990^{\text {th }}$, Orthodox believers in Ukraine have been divided among three separate church jurisdictions.

Only at December 15, 2018 two of them - the Ukrainian Orthodox Church of Kyiv Patriarchate and the Ukrainian Autocephalous Orthodox Church united, forming a new structure - the Orthodox Church of Ukraine (Ukrainian Orthodox Church). During 2019, ca. 600 parishes of the third (and the largest by number of parishes) Ukrainian Orthodox Church of Moscow Patriarchate (the UOC MP) joined the new church, but many others throughout Ukraine as for now still belong to that one in connection with the Russian Church.

Lviv region. The population of Lviv region is marked by an extremely high level of religious activity revealed by sociological research as early as in the Soviet period. In 2019, there were 3114 religious communities of various churches and denominations. Catholic confessions comprise 1707 (54.8\%), with 1568 (50.3\%) Greek-Catholic and 139 (4.5\%) Roman Catholic ones [21]. Orthodox confessions involve 979 religious communities (31.4\%) representing mostly new independent Orthodox Church of Ukraine.

Ivano-Frankivsk region. There were 1354 religious communities in the region in 2019 . The majority of them are Catholic - 706 (52.1\%), among them Greek-Catholic comprise 676 (49.9\%) and Roman Catholic - $30(2.2 \%)$ [21]. Orthodox denominations embrace 496 religious communities $(36.6 \%)$, also mostly of the new Orthodox Church of Ukraine.

Ternopil region. There were 1757 religious communities on the territory of Ternopil region in 2019. Catholic denominations (Ukrainian Greek-Catholic and Roman Catholic Churches) include 895 religious communities $(50.9 \%)$, among them Greek-Catholic comprise 805 (45.8\%) and Roman Catholic - 90 (5.1\%) [21]. Orthodox confessions have 678 communities (38.6\%), most numerous of them being the new Orthodox Church of Ukraine. The number of communities of the Ukrainian Orthodox Church of Moscow Patriarchate is much lesser, they exist mostly in the northern part of the region.

Zakarpattia region. In 2019 there were 1875 religious communities. Orthodox denominations have 712 communities (38.0\%), mostly representing the Ukrainian Orthodox Church of Moscow Patriarchates. Catholic denominations have 534 communities $(28.5 \%)$, among them Greek-Catholic (here they are dependent directly to Rome, not Kyiv) comprise 442 (23.6\%) and Roman Catholic - 92 (4.9\%) [21].

Chernivtsi region. There are 1301 religious communities registered on the territory of Bukovyna in 2019. Orthodox denominations have 627 communities (48.2\%), representing the Ukrainian Orthodox Church of Moscow Patriarchate, new Orthodox Church of Ukraine, and Russian Orthodox Old Believers' Church. Catholic denominations include 61 communities (4.7 \%), among them 28 (2.2\%) are Greek-Catholic and 33 (2.5\%) - Roman Catholic ones [21]. 
Khmelnytskyi region. In 2019, there were 1908 religious communities. The Orthodox Churches have 1340 communities (70.2 \%), and the Ukrainian Orthodox Church of the Moscow Patriarchate is the largest one by the number of parishes. Catholic denominations involve 209 religious communities (10.9\%), in particular, 79 (4.1\%) Greek-Catholic and $130(6.8 \%)$ Roman-Catholic ones [21]. The Roman Catholic communities have recently become more active in the region and its capital.

Volyn region. In 2019, there were 1619 religious communities in the region. Orthodoxy is dominant among religious denominations in Volyn - there are 1100 communities there (67.9\%). The confessional structure is characterized by the prevalence of the Ukrainian Orthodox Church of Moscow Patriarchate, much less representation of new Orthodox Church of Ukraine [26]. Catholic denominations have only $46(2.9 \%)$ religious organizations, among them there are $22(1.4 \%)$ Greek-Catholic and 24 (1.5\%) Roman Catholic ones [21].

Rivne region. There were 1566 religious communities in Rivne region in 2019. Orthodox denominations - 1025 communities $(65.5 \%)$ - dominate. The largest as to its number is the Ukrainian Orthodox Church of Moscow Patriarchate. The number of communities of the Orthodox Church of Ukraine is increasing. Catholic confessions have 27 communities (1.7\%), among them $12(0.7 \%)$ are Greek-Catholic and $15(1.0 \%)$ - Roman Catholic ones [21]. In recent years, the number of Orthodox, Protestant and other communities has increased, while the number of Catholic churches has remained the same.

At the same time, according to the latest sociological surveys [25], among the population of Western Ukraine (excluding Khmelnytsky region), $35.8 \%$ of the inhabitants are faithful of the Ukrainian Greek-Catholic Church, $25.3 \%$ belong to the Orthodox Church of Ukraine and the former Ukrainian Orthodox Church of Kyiv Patriarchate, $8.2 \%$ to the Ukrainian Orthodox Church of Moscow Patriarchate, $1.3 \%$, to the Roman Catholic Church, $1.1 \%$ to the Protestants. Other $14.2 \%$ of the population consider themselves "just Orthodox" $-14.2 \%$, and $7.8 \%-$ "just Christians".

Characteristics of main centres of pilgrimages and religious tourism in Western Ukraine. A majority of religious and pilgrimage objects and places in Western Ukraine belong to Orthodox and Catholic churches. They include monasteries, miraculous icons and holy relics as well as the so-called holy places (monasteries built in caves, on rocky hills and the places of apparition of Virgin Mary) (fig. 1). Among non-Christian confessions, a wide pilgrimage network belongs to Hasid Jews. Many Ukrainian settlements are known for tsadiks who were born or lived there with their burials still remaining.

Lavras and monasteries are the most important centres of religious tourism and pilgrimage in the west of Ukraine. Lavra (Gr. - passage) is a name of large and the most significant Orthodox and Greek-Catholic monasteries subordinated to the highest church authorities.

Description of the main Lavras and monasteries of the region - the destinations of religious trips and pilgrimage - is provided below. Notably, a lot of them have the same name of "SviatoUspensky" - in honor of the feast of Uspennia (Dormition or Assumption) of the Presviata Bohorodytsia (The Most Holy Mother of God or Theotokos) as one of the most adored religious feasts among the Ukrainian people.

Holy Dormition Pochayiv Lavra (located in the town of Pochayiv, Kremenets district, Ternopil region, 16-21 $1^{\text {st }}$ centuries) (fig. 2). The first monks settled down in natural caves on Pochayiv Hill as early as in 1240-1241. A first record of the monastery in Pochayiv dates back to 1527 . During the period of 1713-1832, Pochayiv Monastery belonged to the Uniate or Greek-Catholic Church (Basilian order). 


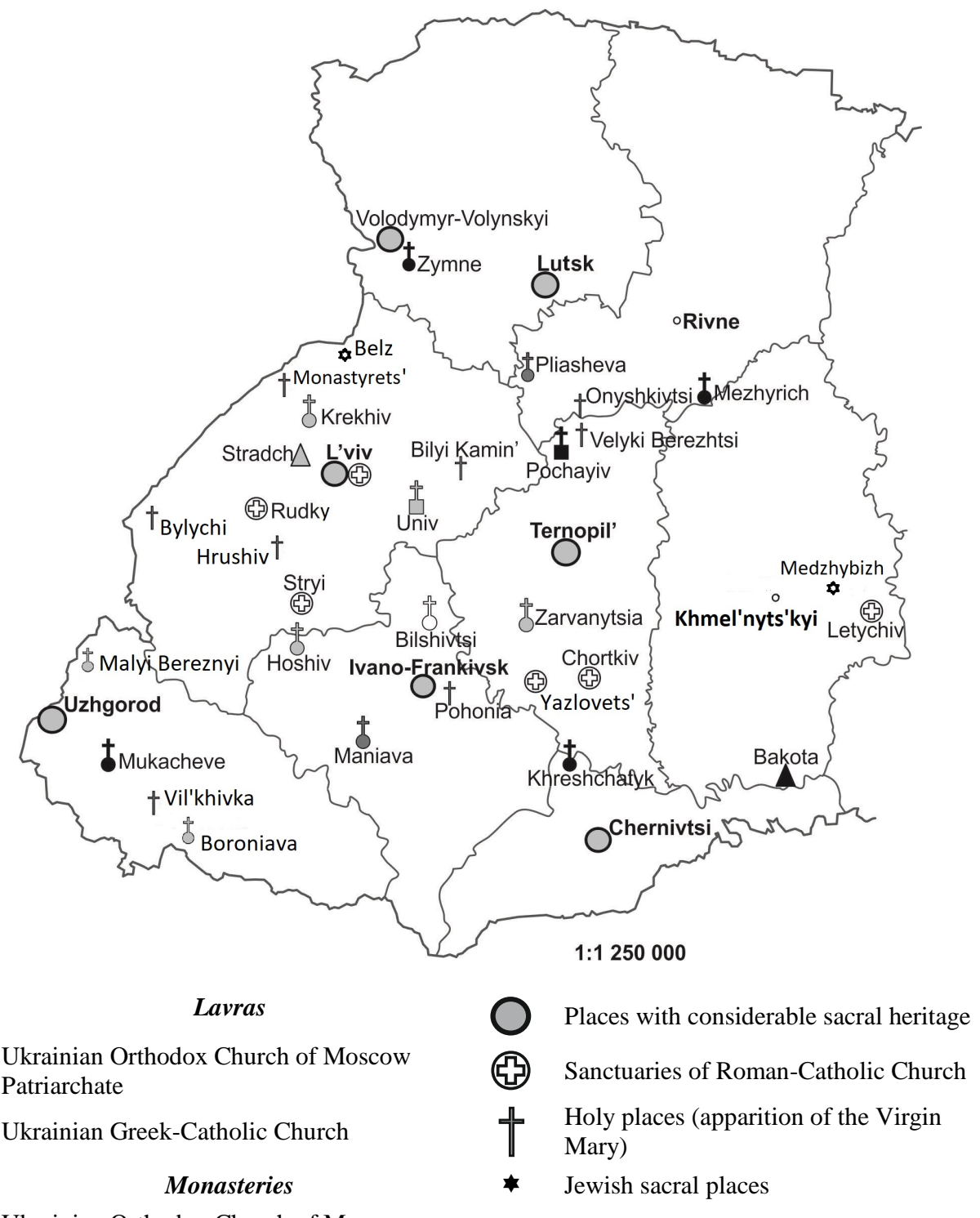

+ Ukrainian Orthodox Church of Moscow

Patriarchate

\section{Rock and cave monasteries}

Orthodox Church of Ukraine (Ukrainian Orthodox Church)

$\triangle$ Orthodox

tf Ukrainian Greek-Catholic Church

$\triangle$ Greek-Catholic

to Roman-Catholic Church

Fig 1. Major centres and places of religious tourism and pilgrimage of the west of Ukraine Рис. 1. Основні місця та центри релігійного туризму і паломництва заходу України 
The main Dormition Cathedral and the majority of contemporary buildings were built there at that time. Later the Lavra belonged to the Russian and Polish Orthodox Churches, since 1989 it is used by the Ukrainian Orthodox Church of Moscow Patriarchate. The monastery complex includes: the Dormition of the Theotokos Cathedral (1771-1782), the Trinity Cathedral (1906-1912), the new constructed Transfiguration Cathedral (2011-2013), cells (1771-1780), Bishop's House (1825), $65 \mathrm{~m}$ high Bell Tower (1861-1869) and an overgate building (1835) [9, 28]. The most important shrines of the Lavra are as follows: miraculous Holy icon of the Theotokos of Pochaiv, the footprint of Mother of God on a stone, and the relics of St. Methodius, St. Job, and St. Amphilochius. Every year, on August 19, a pilgrimage from the village of Dovzhok near Kamyanets-Podilskyi is undertaken to Pochayiv. Other pilgrimages to the Lavra take place on all great Orthodox feasts. There is a hotel for pilgrims with the rooms of different price categories on the territory of the Lavra: rooms for 10 persons (provided only for groups), separate rooms with facilities in the corridor and separate rooms with all facilities. Pilgrims make use of a tour agency, refectory (with free and paid food), parking-lot and leftluggage service. N. B. Pilgrims from the UOC MP, the Russian Orthodox Church and some other foreign Orthodox Churches with close ties to the Moscow Patriarchate usually are warmly welcomed in the Lavra, but guests from other Ukrainian Churches, Catholics and Protestants may face here some difficulties.

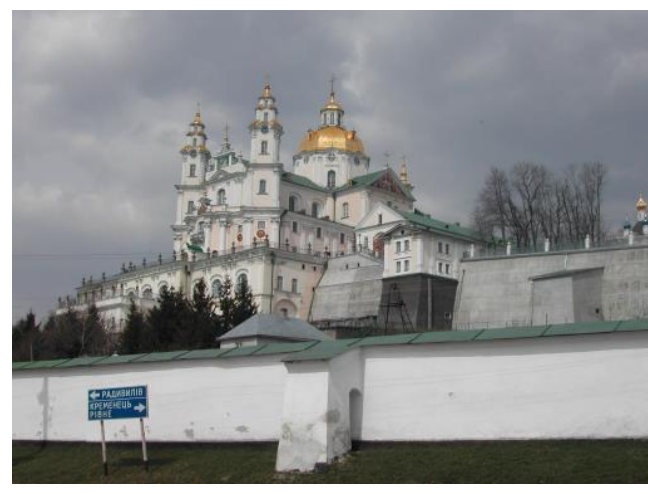

Fig. 2. Holy Dormition Pochayiv Lavra (photo made by T. Hrynchyshyn)

Рис. 2. Свято-Успенська Почаївська Лавра (фото Т. Гринчишина)

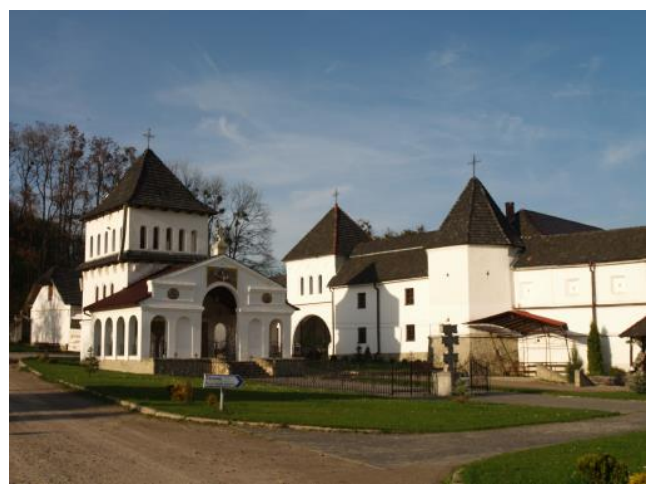

Fig. 3. Holy Dormition Univ Lavra of the Studite Rite (photo made by T. Hrynchyshyn) Рис. 3. Свято-Успенська Унівська Лавра Студійського уставу (фото Т. Гринчишина)

Holy Dormition Univ Lavra of the Studite Rule (village of Univ, Peremyshliany district, Lviv region, $16^{\text {th }}$ century, belongs to the Ukrainian Greek-Catholic Church). The Monastery was built in the $15^{\text {th }}$ century as a defence complex (of a square form, surrounded by stone walls, with four corner towers (fig. 3); there was a high rampart and a deep moat up to the beginning of the $19^{\text {th }}$ century) [9]. Nowadays, the Monastery consists of an old stone and a new wooden churches, fortress walls with two towers, cells, the Metropolitan House and the Retreat House for 40 persons [24]. It is one of the largest pilgrimage centres in Western Ukraine: twice a year two- or three-day walking pilgrimages are made here from the St. Michael's Church in L'viv (before the third Sunday of May as a feast of the local miraculous icon of the Theotokos of Univ - mostly by young people, and at August 25-28). 
The Zymne Holy Dormition Convent at the Holy Mountain (Uspensky Sviatohirsky Convent; village of Zymne, Volodymyr-Volynskyi district, Volyn region, $15-16^{\text {th }}$ centuries, belongs to the Ukrainian Orthodox Church of Moscow Patriarchate). The Convent started from caves and an underground church as early as in the pre-Mongolian period. A first record of the Convent dates back to 1458. The Convent complex includes the Dormition of the Theotokos Cathedral (1495-1550), fortress walls with towers $\left(15-16^{\text {th }}\right.$ centuries), the Holy Trinity Church (1567), an underground St. Varlaam's church, a refectory $\left(15-16^{\text {th }}\right.$ centuries), and an overgate bell tower (1898) [9]. The main shrine of the Convent is a miraculous icon of the Mother of God of Zymne. Pilgrimage to the Convent is undertaken annually on November 27. There is a hotel for pilgrims there.

The Mezhyrich Holy Trinity Monastery (the village of Mezhyrich, Ostroh district, Rivne region, 15-17 ${ }^{\text {th }}$ centuries, belongs to the Ukrainian Orthodox Church of Moscow Patriarchate). It was founded by the monks of Kyiv-Pechersk Lavra. A first record of the Monastery dates back to the chronicles of the $13^{\text {th }}$ century. The main temple of the Monastery - the Holy Trinity Church - was built by Prince Constantine of Ostroh in 1523-1530 [9]. The main local shrine is an icon of the Theotokos-Hodigitria of Mezhyrich. There are also the icons of St. Anthony and St. Theodosius of Pechersk here.

The Maniava Skete (monastery, the village of Maniava, Bohorodchany district, IvanoFrankivsk region, $17-18^{\text {th }}$ centuries, belongs to the Orthodox Church of Ukraine). It was founded by St. Job Kniahynytskyi in 1606. Beginning with 1621, the Monastery was surrounded by stone walls with three defence towers. In 1785 it was closed by the Austrian government within a religious reform of Emperor Josef II. The Skete was one of the sites of cultural life in Galicia, possessed a large library, and was famous for its iconostasis made by Ukrainian painter Job Kondzelevych. In 1980, the History and Architecture Museum was opened there. In 1998, the Skete became Maniava Monastery of the Exaltation of the Holy Cross [9]. The architectural complex of the Monastery is an ensemble of brick, stone and wooden buildings surrounded by high walls with towers and loopholes. The most important shrine is a miraculous icon of the Mother of God "Deliveress" ( $18^{\text {th }}$ century), which has a miraculous power of healing possession.

St. George's Monastery on Cossack Graves (village of Pliasheva, Radyvyliv district, Rivne region, 1910, belongs to the Orthodox Church of Ukraine). It was built on former Zhuravlykha Island on Pliashivka stream to commemorate the Cossacks who died here in the Battle of Berestechko with Poles in 1651 (fig. 4). The complex includes Cossack graves, St. Michael's Cossack wooden church brought from the village of Ostriv $\left(17^{\text {th }}\right.$ century), three-altar St. George's (Yuriy the Dragon Fighter's) Cathedral, a two-storey building with cells, refectory, Bishop's Chambers, hotel and children's asylum [9, 29]. The main feasts of the Monastery are that of Yuriy the Dragon Fighter great martyr (May 6), and at the ninth Sunday after Easter when religious processions and pilgrimages take place.

Krekhiv St. Nicolas' Basilian Monastery (village of Krekhiv, Zhovkva district, Lviv region, $17^{\text {th }}$ century, belongs to the Ukrainian Greek-Catholic Church). It was founded in 1613 by Joel and Sylvester, monks of Kyiv-Pechersk Lavra, who settled down in the caves made in Tymosh Rock, $12 \mathrm{~km}$ from the town of Zhovkva. In 1721 Krekhiv Monastery joined the Uniate (GreekCatholic) Church. Its main temple is St. Nicholas' stone church (1721-1737), built instead of the Holy Trinity wooden church. The main shrines of the Monastery are two miraculous icons: the Mother of God of Verkhrata (or Krekhiv) icon and St. Nicolas the Wonder-working icon. The Monastery has been famous for its sin releases: in the $17-18^{\text {th }}$ centuries, pilgrims from the 
Dnipro and Don regions, Wallachia, Greece and Crete were coming there [9, 24]. After Basilians had returned to the Monastery in 1990, thousands of believers come there on Feast of Saint Nicholas in the second half of May.

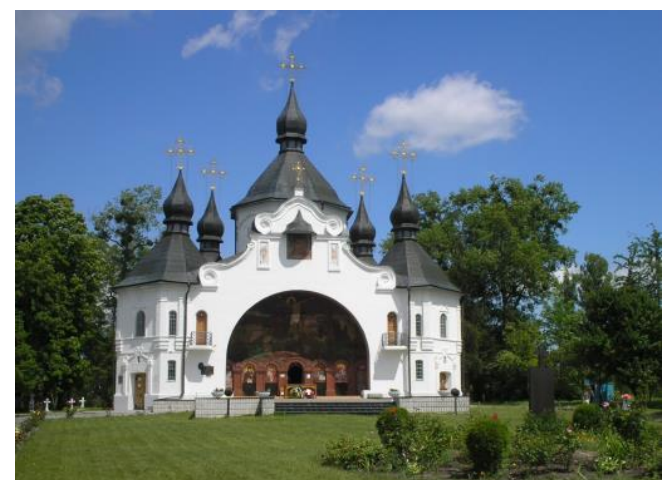

Fig. 4. St. George's Monastery on Cossack Graves (photo made by T. Hrynchyshyn) Рис. 4. Свято-Георгіївський монастир на Козацьких Могилах (фото. Т. Гринчишина)

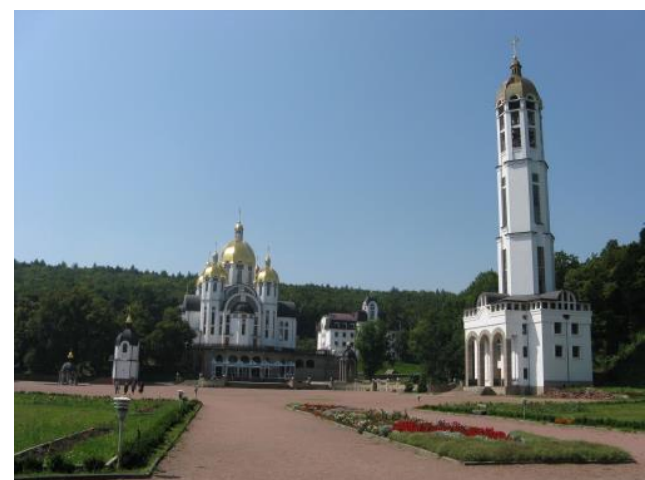

Fig. 5. Marian Spiritual Centre in Zarvanytsia (photo made by Yu. Zinko)

Рис. 5. Марійський духовний центр у Зарваниці (фото Ю. Зінька)

Hoshiv Transfiguration Basilian Monastery (village of Hoshiv, Dolyna district, IvanoFrankivsk region, 15-17 th centuries, belongs to the Ukrainian Greek-Catholic Church). The Church and the Monastery were built in 1570, and in 1629 they were rebuilt after destruction. The Monastery complex on Yasna Hora (Bright Hill) includes a church (1842), monastic cells and outbuildings. The main shrine of the Monastery is Hoshiv icon of the Mother of God, a replication of Czestochowa icon, which due to its miracles got the name of the "Queen of the Carpathians". In 2009, Pope Benedict XVI blessed and sanctified golden crowns for Hoshiv miraculous icon, and the Monastery was awarded a decree according to which it was declared the Great Basilica and became one of the great Mariya's pilgrimage places of the Catholic Church.

Marian Spiritual Centre in Zarvanytsia (village of Zarvanytsia, Terebovlia district, Ternopil region) - the world-famous Marian pilgrimage centres (fig. 5), one of the largest sanctuaries of the whole Ukrainian Greek-Catholic Church. Acquired special significance in 1867. Nowadays it includes a complex of churches, religious buildings and Stations of the Cross. Among them there are: the Parish Holy Trinity Church (1754), were a miraculous icon of the Mother of God of Zarvanytsia is kept; a chapel (1991) near a spring with healing water and pump-rooms; the Retreat House; the Holy Trinity Monastery of the Studite Rule (2001); a wooden Church of the Nativity of the Theotokos (2002); the Mother of God of Zarvanytsia Cathedral (2000) on the slope of the hill in the western outskirt of the village; an architectural composition of the icon of the Mother of God of Zarvanytsia; a four-storey bell tower (height with a cross $-75 \mathrm{~m}$ ); an overgate Annunciation Church; a large square and Stations of the Cross; a singing field for 50,000 people for art and religious events in the southern part of the village [17]. Pilgrimages take place during the whole year, and the central Sunday of July is the day of annual allUkrainian Pilgrimage of the Ukrainian Greek-Catholic Church. Another well-known pilgrimage of Ukrainian migrants and their families is the one undertaken in August from town of Sambir in Lviv region to Zarvanytsia annually since 2006. 
As geography of important pilgrimage monasteries - religious centres of Western Ukraine shows, they are primarily concentrated in Lviv, Volyn, and Ternopil regions. At the same time, there exist well known religious and pilgrimage centres of regional importance represented by monasteries. For example, such role is played by monasteries in Transcarpathia (St. Nicolas' Convent of the Ukrainian Orthodox Church of Moscow Patriarchate in Mukacheve and other numerous monasteries of that Church in villages, the Greek-Catholic Basilian Monasteries in villages of Malyi Bereznyj and Boroniava, Khust district), and Chernivtsi (St. John's the Theolog Monastery in village of Khreshchatyk, Zastavna district) regions.

The sanctuaries of the Roman Catholic Church comprise a special group of pilgrimage places in the west of Ukraine [13, 24].

Sanctuary of Gracious Mother of God and Divine Mercy - the Metropolitan Basilica, Latin Cathedral of the Assumption of Blessed Virgin Mary on the Cathedral Square in Lviv is the main temple of the Lviv Archdiocese of the Roman Catholic Church and the best known and popular pilgrimage place among Roman Catholics (fig. 6).

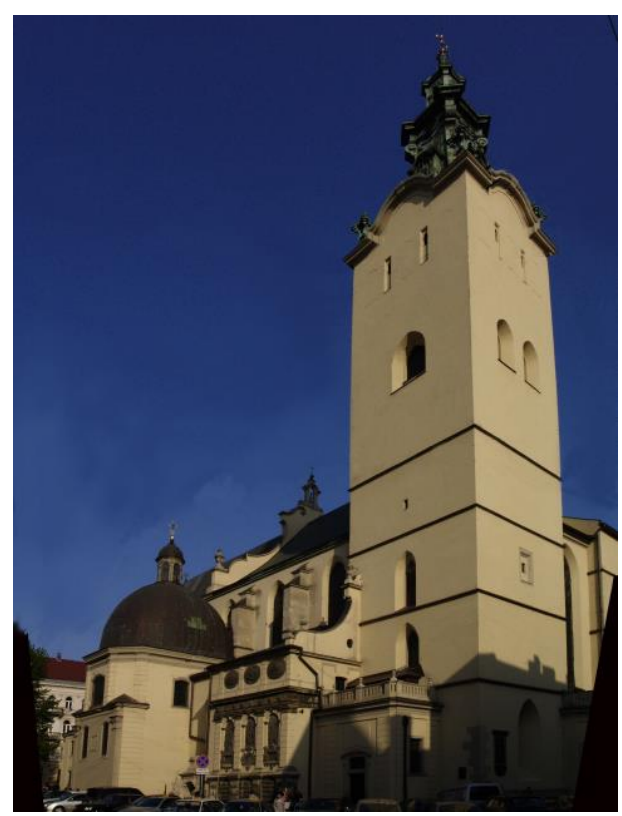

Fig. 6. Latin Cathedral of the Assumption of Blessed Virgin Mary in Lviv (photo made by T. Hrynchyshyn)

Рис. 6. Латинська катедра Успіння Пресвятої Діви Марії у Львові (фото Т. Гринчишина)

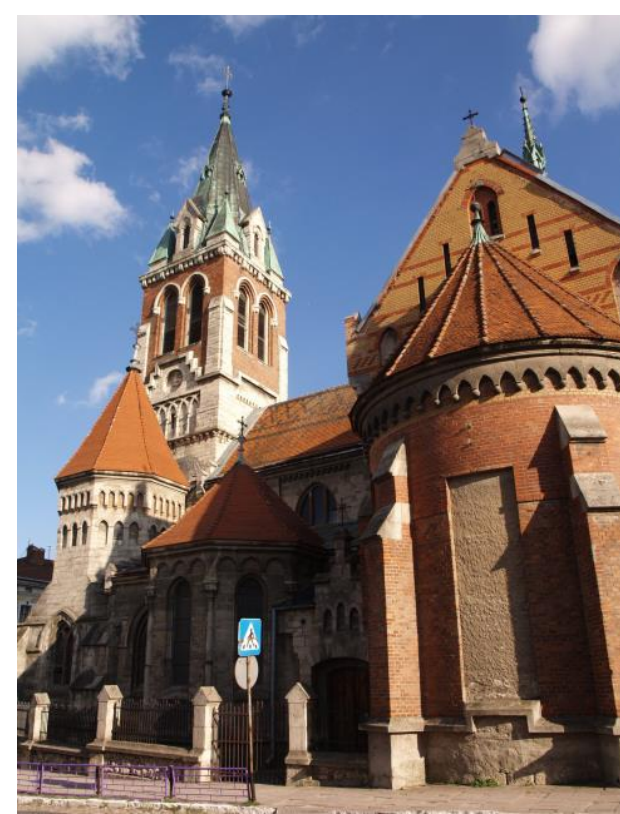

Fig. 7. Church of St. Stanislav in Chortkiv (photo made by T. Hrynchyshyn)

Рис. 7. Костел св. Станіслава в Чорткові (фото Т. Гринчишина)

In a front of the icon of the Gracious (Merciful) Mother of God (1598) the Polish King Jan Kazimierz in 1656 made the solemn vows, choosing the mother of God the Queen of Poland. After the coronation of the icon in 1776, the Church acquired the status of a Sanctuary of the Mother of God, the Merciful, and in 1949 it also became a Sanctuary of Divine Mercy. 
There are also other notable objects of worship in the temple's side chapels and altars: a copy of the famous miraculous icon of Our Lady of Belz-Częstochowa, parts of relicts of St. Pope John Paul II and St. John of Duklia. Moreover, the full relicts of St. Joseph Bilczewski, Lviv Roman-Catholic Archbishop in the years 1900-1923, and St. Zigmund Gorazdowski, priest and guardian of the poor, previously buried at Lviv cemeteries, now are kept in the Cathedral. Both of them were proclaimed blessed in June 2001, the saints in October 2005.

Sanctuary of St. Anthony of Padua. Lviv is the oldest place in Ukraine were Franciscans stay. In the city, they have been present in four different places with a rich history. The traditionally solemn Sanctuary of St. Anthony in Lviv attracts many faithful who come to their patron with different problems. The church on Lychakiv hill obtained status of sanctuary in June 1995, and the icon of the Saint is contained in its main altar.

Sanctuary of Mother of God of Vynnyky. The Church of the Assumption of the Blessed Virgin Mary in adjacent to Lviv town of Vynnyky was erected in 1766. On November 27, 2016, the local icon of the Mother of God of Vynnyky was crowned and the church was elevated to the dignity of the sanctuary.

Sanctuary of the Mother of God the Patroness of Human Hopes. The Cathedral of the Nativity of Virgin Mary in the town of Stryi, Lviv region was built in 1425. It has been rebuilt for several times. In 1995, it was declared the Sanctuary, and in 2001, the Holy Father John Paul II sanctified the crown of the Mother of God of Stryi while praying during his Apostolic visit to Ukraine.

Sanctuary of Our Lady of Bilshivtsi (in town of Bilshivtsi, Halych district, Ivano-Frankivsk region). The former Franciscan Monastery and Church of the Visitation of the Blessed Virgin Mary - one of the most prominent samples of Late Baroque architecture of the 18th century in Galicia [13]. It was founded in 1624 by the monks of the Order of Discalced Carmelites invited to the village by its owner. The Carmelites Monastery is built on a high hill. It was surrounded by brick walls together with the cathedral. The height of the walls reached $2 \mathrm{~m}$ in some places, and the width was about $1 \mathrm{~m}$. Only the western building of cells has been preserved. In the $19^{\text {th }}$ century the Carmelites Monastery in Bilshivtsi was one of the largest in Ukraine as evidenced by the documents kept in its archive before World War I. According to the 1788 description, the archive had 701 volumes of different materials. The Monastery was known for its miraculous icon of the Mother of God of Bilshivtsi. At the end of the World War II, the Carmelites took it to Gdansk (Poland), where it is now kept in St. Catherine's Cathedral [9, 13]. In 2002, the Monastery was given into custody of Franciscan monks from Poland.

Sanctuary of Blessed Virgin Mary of the Holy Rosary (town of Chortkiv, Ternopil region). The Sanctuary in Chortkiv is not enough known among Roman Catholic shrines in Ukraine. The status of sanctuary was granted to St. Stanislaus' Cathedral not long ago - in 2009, after solemn coronation of the replica of a miraculous icon of the Holy Mother (fig. 7) [13]. The first cathedral that was dedicated to St. Stanislaus, martyr and bishop, was built together with the Dominican Monastery in 1619. The icon of the Holy Mother of St. Rosary originates from the 16th century and was previously kept in Ostrovnia near Vitebsk (now in Belarus). In 1663 King Jan Kazimir presented it to Dominicans in Chortkiv, this being evidenced by Latin inscription: "Jan Kazimir, the King of Poland, was in Chortkiv with a miracle-making icon from Ostrovnia" [13]. After the expulsion of Dominicans from Chortkiv (in 1946), the icon was moved to Warsaw, where it is kept now in the Dominican Cathedral of St. Hyacinth.

Sanctuary of the Holy Mother of Letychiv in town of Letychiv, Khmelnytskyy region. The Cathedral was returned to Roman Catholics on July 5, 1992 [13]. Five years later official 
pilgrimages to the holy icon of Mother of God of Letychiv resumed. Many thousands of the faithful, with almost one thousand of walking pilgrims among them come here.

Other notable Roman Catholic pilgrimage places in Western Ukraine with status of sanctuaries are: Our Lord Jesus in Agony of Myliatyn in town of Kamyanka-Buzka; Holy Cross in village of Berezdivtsi, Mykolayiv district; Our Lady of Perpetual Help in town of Mostyska and Blessed Virgin Mary of Fatima in village of Krysovychi, Mostyska district; Blessed Virgin Mary in town of Rudky and Blessed Virgin Mary of La Salette in village of Lanovychi, Sambir district; Our Lady of Providence in town of Nyzhankovychi and St. Anna in village of Susidovychi, Staryi Sambir district; Our Lady the Queen of Peace in town of Ivano-Frankove, Yavoriv district - all of them are located in Lviv region, and also Blessed Marcelina Darovska in town of Yazlovets, Buchach district, Ivano-Frankivsk region and Our Lady of the Scapular in village of Polupanivka, Pidvolochysk district, Ternopil region [5].

Ukraine, a motherland of Hasidism, has tens of objects of Hasid pilgrimages as well as the largest number of burials of Hasid saints. In Western Ukraine, it is primarily the tomb of the founder of Hasidism, Baal-Shem-Tov (Besht) in the town of Medzhybizh, Letychiv district, Khmelnytskyi region (fig. 8). Among other Hasid pilgrimage places, there are the following burials of Hasid saints [33]: Rabbi Menachem-Mendel Kosover, his son and grandson - tzadik from Kosiv, founders of the Kosiv dynasty of tsadiks (town of Kosiv, Ivano-Frankivsk region); Rabbi Shalom Rokeach (1779-1855) - a founder of Belz Hasid dynasty (town of Belz, Sokal district, Lviv region) (fig. 9); Rabbi Tzvi (Hersh) from Zhydachiv (1762-1831) - a founder of Zhydachiv Hasid dynasty (town of Zhydachiv, Lviv region); Rabbi Zachary Mendel (?-1791) the author of "Zachary Menorah", "Zachary Meshulam", and "Zachary Iamevin" (town of Pidhaytsi, Ternopil region); Rabbi David Moshe Fridman (1827-1904) - a founder of Chortkiv Hasid dynasty (town of Chortkiv, Ternopil region); Rabbi Dov-Ber of Mezeritch (Mezhyrich, or Maggid of Mezritch) (1704-1772) - a leader of Hasid movement and a teacher of Hasid tsadiks (town of Hannopil, Khmelnytskyi region); Rabbi Jacob Josef of Polonne (1710-1784) - a Hasid tsadik, a pupil of the Besht, was the first to write down teaching of Hasidism (town of Polonne, Khmelnytskyi region); Rabbi Pinchas of Korets (1728-1790) - a pupil of the Besht, an outstanding Hasid mentor (town of Shepetivka, Khmelnytskyi region) [33]. Pilgrims visit these places mostly during Jewish feasts. As a rule, such trips are organized by travel agencies or religious Jewish organizations.

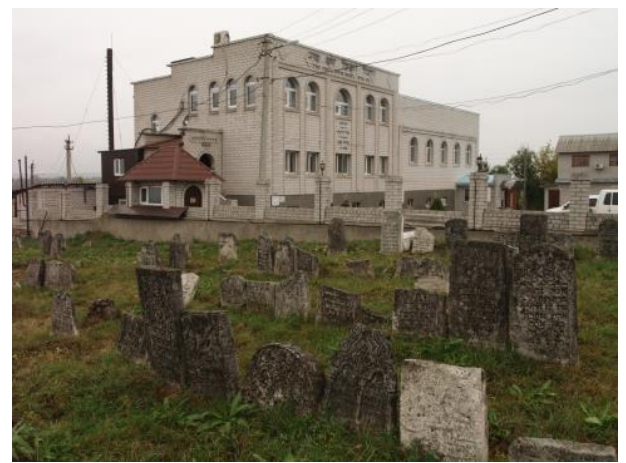

Fig. 8. Synagogue in Medzhybizh (photo made by T. Hrynchyshyn) Рис. 8. Синагога в Меджибожі (фото Т. Гринчишина)

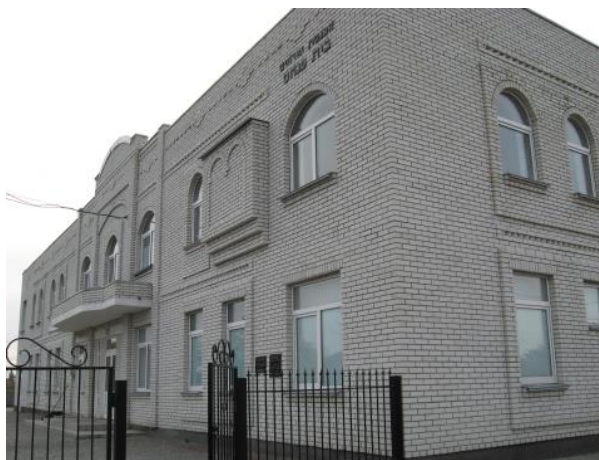

Fig. 9. Synagogue in Belz (photo made by T. Hrynchyshyn) Рис. 9. Синагога в Белзі (фото Т. Гринчишина) 
Touristic and pilgrimage streams to major religious centres have been insufficiently studied in Ukrainian research. The data from Internet sources and surveys show that Pochayiv Monastery (with more than 50,000 visitors), Krekhiv Monastery (more than 30,000 visitors) and Zarvanytsia Marian Spiritual Centre (more than 100,000 visitors) are the most often visited sacral centres in the region.

Lviv and other regional centres of Western Ukraine as destinations of religious tourism and pilgrimage. Cities - regional centres of Western Ukraine as well as some separate historical places are centres of religious tourism and pilgrimage.

Lviv (with its suburbs - towns of Vynnyky, Briukhovychi and Rudne) is the most prominent religious centre of Western Ukraine (fig. 10), and the second, after Kyiv, in the country. As of now, there are ca. 110 typical Christian church buildings here (and some other churches are in process of construction), dozens of monasteries and nuns' houses [8, 15]. Lviv is a seat of the Administrative Centre of the Roman Catholic Church in Ukraine, and a place of episcopal seats of a local Greek-Catholic and three Orthodox eparchies, as well as of the Ukrainian eparchy of the Armenian Apostolic Church.

There are the Ukrainian Catholic University, the Greek-Catholic and Roman Catholic Seminaries and the Theological Academy of the Orthodox Church of Ukraine in the city and suburbs. Also, various Protestant denominations, as well as the Jehovah's Witnesses have their important religious institution and numerous communities here.

The richness of architecture and interiors, the numerous Christian shrines stored in the temples of the city, make them a must-see part of excursions in Lviv. In addition to three Roman Catholic Sanctuaries, already mentioned above, there are a lot of pilgrimage places in the city and its vicinity [8].

For Greek-Catholics the most important destination is the Archbishopric Cathedral of Sviatoho Yura (St. George's) - a main church of the Lviv Archeparchy and former seat of leaders of that entire Church (fig. 11).

The main local object of worship is a Terebovlia miraculous icon of the Most Holy Theotokos (17 ${ }^{\text {th }}$ century). It was moved here, rescuing from Turkish attacks, in 1674 from the mentioned town in Podillia. The largest pilgrimages to the icon take place on October 14 - the feast of Intercession of the Theotokos.

A copy of the Shroud of Turin has been exhibited here since December 2005 (among all registered and blessed by Pope copies of the Shroud in the world, this one is the eighth, made specially for Ukraine). Relicts of many Saints (incl. St. Nicolaus, St. Peter the Apostle, St. Charbel etc) are kept and adorated in the church.

In the crypt of the Cathedral are buried the leaders of the Church in 19-20 ${ }^{\text {th }}$ centuries: Cardinal Sylvester Sembratovych, Metropolitan Andrey Sheptytskyi, Patriarch Yosyf Slipyi, Metropolitan Volodymyr Sterniuk, Cardinal Ivan Myroslav Lubachivskyi. No one of them is already proclaimed a Saint or Blessed, but that does not stop people who come here to pray.

Basilian Church of St. Andrew (1600-30, till the end of $18^{\text {th }}$ century it belonged to the closed Bernardyn's Monastery) is a prominent example of the Renaissance architecture. A miraculous icon of the Mather of God the Painful of Derevnia (1786) was moved here in 1990 from village in Zhovkva district and crowned by Pope John Paul II in 2001. Nearby is the revered figure of the Virgin Mary, which formerly toped a fountain on the Marian Square in the centre of the city (now there is a copy of it).

The Church of Blessed Klymentiy Sheptytskyi (former Roman Catholic church of St. Kazimir) has a significant collection of old icons and particles of relics of many Saints, 
rescued from destruction. Also, a new Museum of Metropolitan Andrew Sheptytskyi is established now on the base of the church.

Numerous churches in Lviv obtain relics of martyrs of the Ukrainian Greek-Catholic Church who were beatified by Pope John Paul II on June 27, 2001 during his visit to Ukraine. The relics of Blessed Martyrs Nicholas Charnetskyi and Vasyl Velychkovskyi (just particle) are located in the Redemptorist's Churches of St. Yosafat and of the Immaculate conception of the Mother of God; relics of Blessed Martyr Mykolay Tsehelskyi - in the Church of the Christ's Resurrection; relics of Blessed Sisters Olympia Bida and Lavrentiya Harasymiv - in the chapel of the main house of the Nuns of St. Joseph, which is named in their honor; particles of relics of Blessed Mather Yosafata Hordashevs'ka, the foundress of the Congregation of Sister Servants of Immaculate Virgin Mary, and Sister Tarsykiya Matskiv, the Martyr - in the Convent of Annunciation of the Mother of God, the main house of the Congregation in Ukraine.

One of largest in Western Ukraine church of the Nativity of the Theotokos (2000) in Lviv's district of Sykhiv owns the relics of Blessed Hryhoriy Lakota, and grave of Blessed Martyr Andriy Ishchak, killed in 1941, can still be found at the old local cemetery near the wooden Church of the Holy Trinity (1600).

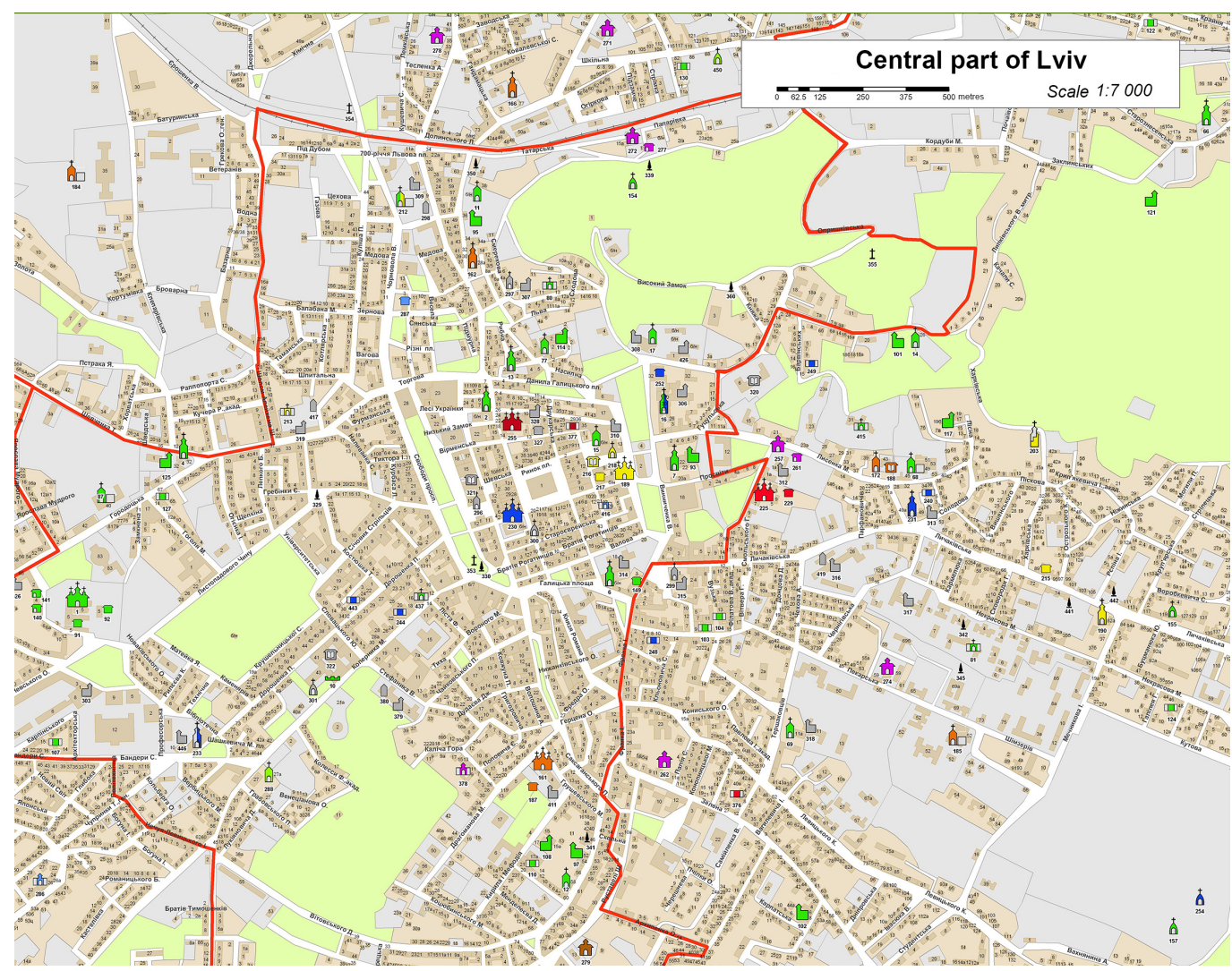

Fig. 10. Religious sites in central part of Lviv as places of pilgrimage (source: T. Hrynchyshyn [8]) Рис. 10. Релігійні об’єкти центральної частини Львова як паломницькі місця (джерело: Т. Гринчишин [8]) 


\section{Legend to fig. 10}

Object / Site

$\begin{array}{lll}\text { parish church } & \begin{array}{l}\text { monks/nuns } \\ \text { house }\end{array} \\ \text { church under } \\ \text { construction } \\ \text { church in a } \\ \text { secular institution }\end{array}$

\section{Religion / Denomination}

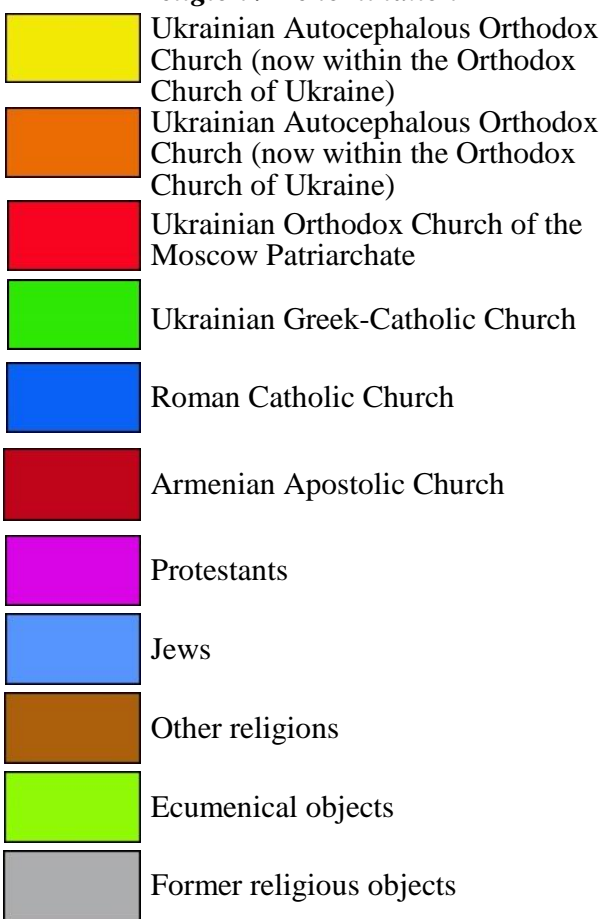

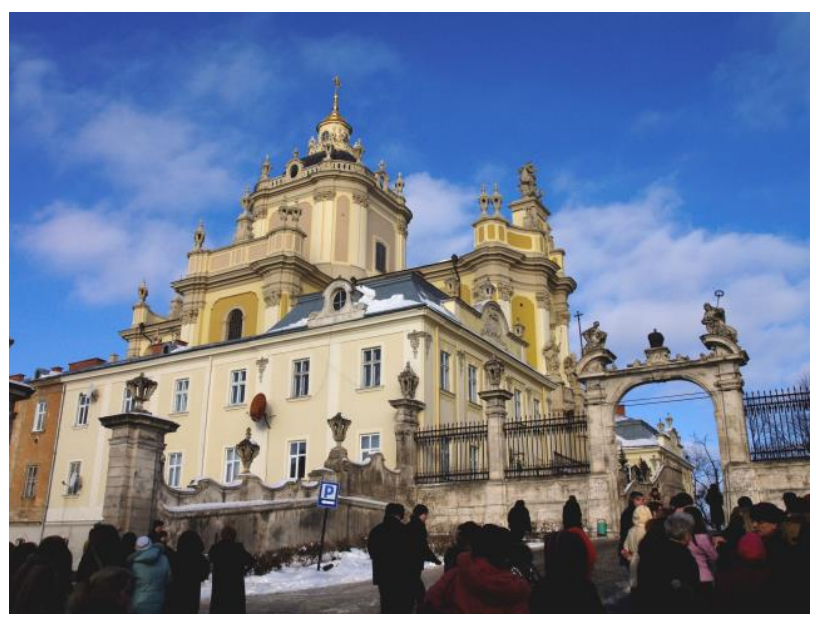

Fig. 11. Archbishopric St. George's Cathedral in Lviv (photo made by T. Hrynchyshyn)

Рис. 11. Архикатедральний Собор Святого Юра (фото Т. Гринчишина)

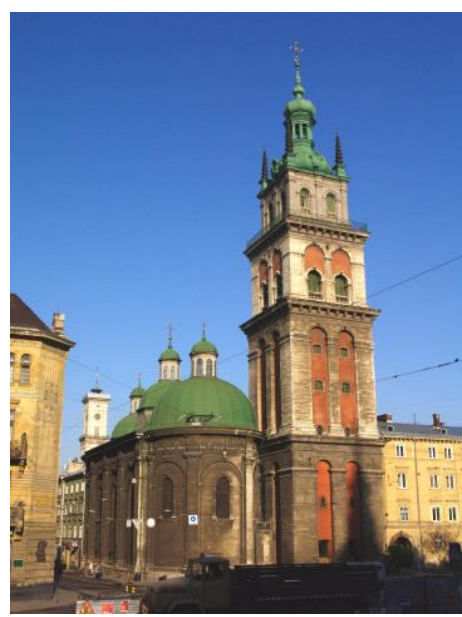

Fig. 12. The Church of the Dormition of the Most Holy Theotokos in Lviv (photo made by T. Hrynchyshyn)

Рис. 12. Церква Успіння Пресвятої Богородиці у Львові (фото Т. Гринчишина) 
There are particles of relics of many Saints in the Church of All Saints of the Convent of Nuns of the Studite Rule. Otherwise, particles of relics of St. Panteleimon the Healer can be found in numerous Catholic and Orthodox churches in Lviv.

There are also numerous objects of worship in the Orthodox churches in Lviv, which now are under various jurisdictions.

In the Church of Dormition of The Most Holy Theotocos on the Ruska street which is one of the oldest in Lviv and now servs as the cathedral of the Lviv eparchy of the Orthodox Church of Ukraine (fig. 12)] are kept the relics of St. Mercury, St. Anastasia of Constantinople and mentioned St. Panteleimon, as well a local miraculous icon of the Theotocos-Hodegetria of Stauropegion.

In the Orthodox Cathedral of the Intercession of the The Most Holy Theotokos (former Roman Catholic Trinitarian Church of St. Nikolaus), the episcopal seat of the Lviv-Sokal eparchy of the same Church, inside the icons are particles of relics of St. Barbara and St. Makariy, Metropolitan of Kyiv.

Particles of relics of St. Nicholas of Myra are kept in the oldest in Lviv church, which has his name, relic of St. Luka Voyno-Yasenetskyi - in the St. Georg's church near Lviv railway station.

The Church of St. Paraskeva-Friday, which boasts a magnificent Renaissance iconostasis of more than 70 icons with the first half of $17^{\text {th }}$ century, owns the miraculous icon of the Mother of God; another one, of the Turkovychi, was brought in 1946 by immigrants from Ukrainian village of Perevisk near Tomasheva (now in Poland). is kept in the Church of the Protection/Intercession of the Theotokos in town of Rudne.

In the St. George's Church of the Ukrainian Orthodox Church of the Moscow Patriarchate, which plays role of the cathedral of the Lviv Eparchy of that Church. Faithful worship a copy of the icon of the Theotokos of Tikhvin, which was written on Mount Athos in 1905 intentionally for Lviv church, and a copy of the Pochayiv icon of the Mather of God (1936). Also, another Christian relic - a particle of a rib of St. Barbara is stored here.

The Armenian Cathedral of the Dormition of the Most Holy Theotokos is an episcopal seat of the Ukrainian Eparchy of the Armenian Apostolic Church and one of the most beautiful churches in Lviv. There is miraculous icon of Mother of God from Kamyanets-Podilskyi and particles of the relics of St. Innocent, the Pope, St. Gregory the Illuminator, the Baptist of Armenia and his son St. Vartanes.

Before World War II, Lviv has very significant Jewish community (ca $32 \%$ of total its population). There were more than 100 synagogues and houses of worship here, mostly destroyed by Nazi during the war One of the most known Jewish symbols of the city was the "Golden Rose" synagogue (built in 1592-1596 and ruined in 1941).

Other cities - centers of Western-Ukrainian regions also have a rich sacral heritage and are important for pilgrims and tourists.

The most visited religious place of Ivano-Frankivsk (former Stanyslaviv or Stanislaw) is the Holy Resurrection Cathedral of the Ukrainian Greek-Catholic Church - thousands of pilgrims come here to worship relics of Peter the Apostle, Blessed Mother Teresa, blessed martyrs Omelian Kovch, and Simeon (Lukach) and Ivan (Sleziuk), bishops of Stanyslaviv [24]. Also popular is the Monastery of Christ the King with a replica of Stanislaw miraculous icon of the Affectionate Mother of God (its original is kept in Gdańsk from the end of $17^{\text {th }}$ - beginning of the $18^{\text {th }}$ centuries; since 2010, when the replica was given to the Monastery, it has become the object of pilgrimages) and the relics of great martyr St. Josaphat (Kuntsevych), the Archbishop 
of Polotsk [24]. Recently, the Greek-Catholic Parish of First-Called Apostles Saints Peter and Paul in Ivano-Frankivsk opened the "Pilgrim" hostel for 50 persons, with a canteen of 50 seats [30].

The Cathedral of the Immaculate Conception of the Blessed Virgin Mary in Ternopil - the main church of Ternopil-Zboriv Eparchy of the Ukrainian Greek-Catholic Church, a former Dominican Cathedral (was built in 1749-1779 in Baroque style), monument of sacral architecture - is a place of constant pilgrimage. There are copies of four most famous in Ternopil region and Ukraine icons of the Blessed Virgin Mary - of Zarvanytsia, Pochayiv, Ternopil and Terebovlia on the cathedral walls [24].

The most well-known religious centres in Volyn region are Lutsk and VolodymyrVolynskyi - one of the oldest cities of Ukraine. Lutsk has St. Apostles Peter and Pauls Cathedral and a Jesuit Collegium - local architectural monuments located in the "Old Lutsk" Historical and Cultural Reserve. Today the Collegium is an educational institution, and the church is the main Cathedral of Lutsk Roman Catholic Diocese (Volyn and Rivne regions). Numerous pilgrims come there, and the underground complex is opened for tours. Lutsk has also the unique Museum of icons with an ancient miraculous icon of the Mother of God of Kholm ( $11^{\text {th }}$ century). An old synagogue - a monument of sacral architecture of the $17^{\text {th }}$ century - has also been preserved in Lutsk [24].

The first record of Volodymyr-Volynskyi in chronicles dates back to 988. This town has been the place of many temples and shrines since the times of Kyivan Rus. In 2001, the "Old Volodymyr" Historical and Cultural Reserve was created in the central part of the town. It includes the Holy Assumption (Mstislav's) Cathedral - the only monument of ancient Rus architecture in Volyn, preserved almost without any changes; St. Vasyls Church $\left(13-15^{\text {th }}\right.$ centuries) with a foundation built in the form of an eight-petal flower (this Church has an original icon of Theotokos-Hodigitria of the $17^{\text {th }}$ century); St. Nicolas' Church (end of the $18^{\text {th }}$ century; was built as a Greek-Catholic Chapel of St. Josaphat (Kuntsevych), in 1800 it was given to the Orthodox Church); Cathedral of the Nativity (beginning of the $18^{\text {th }}$ century) and others [24]. The majority of temples of the Reserve belong to Orthodox believers (of Moscow Patriarchate) and Roman-Catholic communities.

Shrines as Pilgrimage Places in Western Ukraine. Numerous shrines are an important component of the pilgrimage-religious movement in Western Ukraine. Sacred sites (sacralreligious) landscapes are divided by the dominance of elements of living and inanimate nature, natural anthropogenic, the combination of natural elements and religious ceremonial structures, and the dominance of religious structures [10]. A special group is formed by the holy places related to the apparition of the Virgin Mary, miraculous icons, healing springs, and old cave monasteries.

God's Hill (Bozha Hora). Above-mentioned Pochayiv Lavra is adjacent to the less known but still much respected by the faithful God's Hill (366 m a. s. 1.), located near the village of Velyki Berezhtsi, Kremenets district, Ternopil region. According to the researcher of Volyn Volodymyr Rozhko, the hill became revered because it has been a place of asceticism of numerous monks since the Princes' times of $9-10^{\text {th }}$ centuries. According to various folk legends, Virgin Mary appeared there and left an imprint of her foot. Regarding the Ukrainian name of the hill (Bozha Hora), there are three versions of its origin: on behalf of the Ants' Prince Bozh, described by Goth historian Jordan; on behalf of the Slavonic tribe Buzhany; from the miracle of the Virgin Mary's apparition [14]. The shrine was restored after Ukraine had gained its independence; the place where the Virgin appeared, the spring and the caves were 
properly decorated, and a new church was built. Pilgrims constantly go to Bozha Hora, but they reach their largest number on the feast of the Pentecost between Easter and Ascension.

Holy Hill (Sviata Hora) is still no well-known place, where the Mother of God appeared, located $60 \mathrm{~km}$ to the east from Lviv between the villages of Bilyi Kamin and Ushnia in Zolochiv district (fig. 13). Here, on the top of the hill, three girls witnessed the apparition of the God's Mother on September 6, 1948. After the apparition of the Virgin, a small spring appeared on the mountain [27]. In the 1990s parishioners and the priest from the village of Ushnia restored a wooden chapel and spring, and since 1998 walking pilgrimages have begun from Lviv to Holy Hill. Nowadays, there have been erected two churches and the Monastery of the Placing of the Robe of Theotocos (the Orthodox Church of Ukraine) on the top of hill.

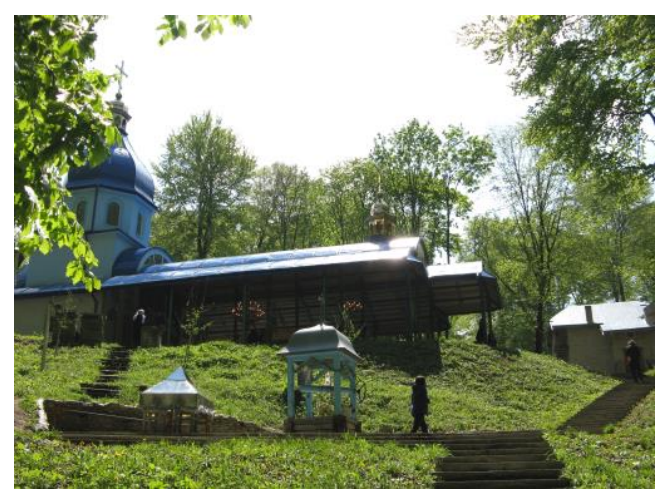

Fig. 13. Holy Hill (Sviata Hora) (photo made by Yu. Zinko)

Рис. 13. Свята Гора (фото Ю. Зінька)

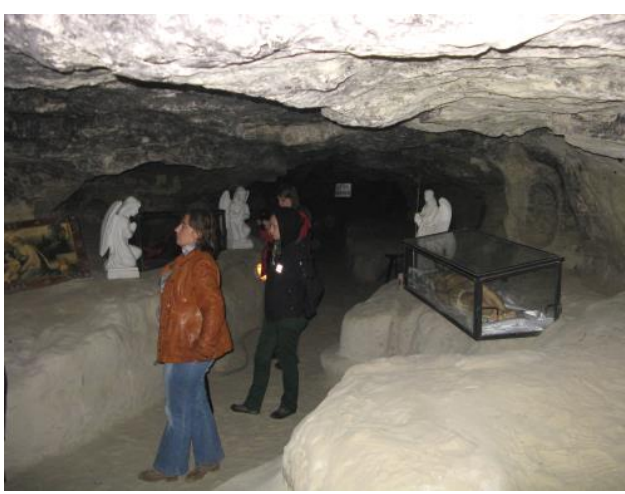

Fig. 14. Stradch Cave Monastery (photo made by $\mathrm{Yu}$. Zinko)

Рис. 14. Страдчанський печерний монастир (фото Ю. Зінька)

Spring (Bath) of Holy Righteous Anna. Also not far from Pochayiv, in the village of Onyshkivtsi, Dubno district, Rivne region, there is the of Holy Righteous Anna's Skete and Spring. In the place of the apparition of St. Anna's icon, a chapel was built to keep the shrine, and since then water from the healing spring has started to flow [31]. According to legends, bathing in it heals many diseases and infertility.

Holy spring in the village of Pohonia. There is a well known healing spring in the Dormition of the Theotokos Basilian Monastery (the Ukrainian Greek-Catholic Church) in the village of Pohonia, Tysmenytsia district, Ivano-Frankivsk region, which possesses a status of the pilgrimage place together with Hoshiv Monastery (Dolyna district, Ivano-Frankivsk region) and Zarvanytsia (Terebovlia district, Ternopil region) [31].

Holy spring in "Pid Dzhublykom" ("Under Dzhublyk") tract. On August 27, 2002, in Irshava district, Zakarpattia region, in the "Under Dzhublyk" tract located between the villages of Vilkhivka and Nyzhnie Bolotne, the God's Mother appeared to two local girls near the spring [31]. The "Under Dzhublyk" tract has become a popular pilgrimage place during recent years and its general way of development is similar to that in Medjugorje in Bosnia and Hercegovina.

Bakota St. Michael's Cave Monastery. The oldest cave monastery of Podillia is located on the steep slope over the Dnister River, so called White Hill, not far from the former village of 
Bakota, which disappeared on bottom of the local water reservoir in 1980s. Cave Monastery appeared on the place of the pagan temple as early as in $12-13^{\text {th }}$ centuries and was active for 300 years to the middle of the $15^{\text {th }}$ century. Partially destroyed by collapse of cliff after water reservoir construction, caves are immersed now into the cliff for more 7-9 $\mathrm{m}$ and the total area of the Monastery is about $760 \mathrm{sq} . \mathrm{m}$ [24]. The Bakota Cave Monastery is the largest and the best-preserved monastery of about 20 monasteries of the Dnister valley. It is the oldest cult underground structure disseminating Orthodoxy in Podillia, a popular place of pilgrimage and religious tourism [24].

Stradch Cave Monastery. This cave monastery (fig. 14) appeared at the end of the $11^{\text {th }}-$ beginning of the $13^{\text {th }}$ century near the village of Stradch, Yavoriv district, Lviv region, when monks settled down in the caves of Stradch Hill. The Hill was named ("Stradch" means "Suffering") in honour of local monks and villagers who were killed here during the Tatar's assault. There have been the Stations of the Cross there since 1936. The most important shrines of Stradch Cave Monastery are miraculous icons - Stradch icon of the Dormition of the Theotokos and the Icon of the Mother of God "Unbreakable (or "Indestructible") Wall", and graves of Father Mykola Konrad and cantor Volodymyr Pryima, the blessed martyrs killed in 1941. Nowadays Stradch complex is a popular pilgrimage place and has status of the main pilgrimage centre of Lviv Archeparchy of the Ukrainian Greek-Catholic Church [16]. Thousands of believers annually took part in the all-Ukrainian pilgrimage of laymen from Lviv to Stradch on June 26.

Other interesting places of pilgrimages are healing springs in villages of Bylychi, Staryi Sambir district, of Hrushiv, Drohobych district, and in "Zahlyna" tract near village of Monastyrok, Zhovkva district - all in Lviv region, as also Holy Spirit's spring near village of Silets, Tysmenytsia district, Ivano-Frankivsk region, and some others [16].

An important role in touristic and pilgrimage movement is played by a number of organizational structures. There are several pilgrimage agencies and cervices, organized by Orthodox and Catholic Churches, their parishes and private people in the Western Ukraine. The best known among them are: the Pilgrimage Centre of Our Lady of Perpetual Help [17], the Patriarchal Pilgrimage Centre and the Pilgrimage Centre "Rafayil" of the Ukrainian GreekCatholic Church [24], St. Christopher's Pilgrimage Centre of the Roman-Catholic Church, the Pilgrimage Centre "Pokrov" of the Orthodox Church of Ukraine, the "Bethlehem" and "Ikhtis" Pilgrimage Centres [24], and others. They inform communities of believers on the planned pilgrimage trips in the region and abroad.

Religious and sightseeing tours in the Western region are offered by travel agencies in Lviv, Ivano-Frankivsk, Ternopil and Lutsk [18, 22]. These tours, in addition to visiting well known Christian places, envisage going to famous historical (castles and palaces) and natural (national parks, caves, waterfalls) attractions. The most popular places of religious tours are Pochayiv Lavra, Krekhiv Monastery, Zymne Monastery, Maniava Skete, Bakota and Stradch Monasteries.

Conclusions

1. In religious terms, Western Ukraine is marked by multiplicity of Christian confessions. Main religious communities belong to the following denominations: Ukrainian Greek-Catholic Church, Ukrainian Orthodox Church (Orthodox Church of Ukraine), Ukrainian Orthodox Church of Moscow Patriarchate, and Roman Catholic Church. Each of main churches has religious centres and places, which play the role of religious tourism and pilgrimage sites. Clear confessional binding of religious and pilgrimage places is unfavourable for interconfessional dialogue in the region. 
2. Main religious and pilgrimage centres in the region are represented by lavras, monasteries, and outstanding sacral objects in large cities (Lviv, Ternopil, Lutsk) as well as by small churches with a status of a sanctuary (in Roman Catholic tradition) or old pilgrimage traditions (Hasid shrines). A special group of visited places is formed by the so-called holy places (shrines) related to the apparition of the Virgin Mary and old cave monasteries. The most visited centres of religious tourism are Pochayiv Lavra, Krekhiv and Univ Monasteries, Zymne Convent, Maniava Skete, Zarvanytsia Marian Spiritual Centre and Christian shrines in Lviv, Lutsk and Volodymyr-Volynskyi. Pilgrimage centres, Christian non-governmental organizations, travel agencies and educational institutions play an important role in the organization of trips to religious places. At the same time, the infrastructure of many centres is insufficiently developed and the collection of statistical data on visitors (pilgrims and tourist groups) is not well organized.

3. Development of religious and pilgrimage centres is related to the development of service infrastructure, service complexes and a network of different types of accommodation. It may be recommended to organize more educational and scholarly events of Ecumenical character and meetings of faithful of different denominations in the well-known religious centres of the region.

Further development of cultural and religious tourism has significant potential in the region. In particular, it is necessary to develop the regional "Route of Wooden Churches" with its further transformation into an international one, which will join the Polish "Route of Wooden Architecture." This planned itinerary can become very popular as many of the wooden churches are on the UNESCO List of Cultural Heritage.

\section{СПИСОК ВИКОРИСТАНОЇ ЛІТЕРАТУРИ}

1. Jackowski A. Pielgrzymowanie. Wydawnictwo Dolnoslaskie, 1998. $312 \mathrm{~s}$.

2. Ostrowski M. Teologia turystyki / Turystyka w naukach humanistycznych / red. R. Winiarski. Warszawa: Wydawnictwo naukowe PWN, 2008. S. 102-116.

3. Robinson M. Sacred Places, Pilgrim Paths: An Anthology of Pilgrimage Paperback. Zondervan, 1998. 224 p.

4. Różycki P. Turystyka a pielgrzymowanie. Wydawnictwo Wam, 2016. 352+16 s.

5. Schematyzm duchowieństwa i parafii Archidiecezji Lwowskiej Obrządku Lacińskiego. Lwów, 2016. S. 72-74.

6. Географія релігійного туризму в Україні: навч. посібник / А. Ковальчук, М. Рутинський, А. Манько, Т. Завадовський, Д. Каднічанський. Львів, 2016. 474 с.

7. Городиський Ю. Я. Територіальні особливості розвитку паломництва у Львівській області // Вісник Харків. нац. ун-ту. № 1128. Серія “геологія - географія - екологія”. 2014. Вип. 41. С. 101-106.

8. Гринчишин T. Львів сакральний: релігійні об'єкти на мапі міста: Атлас-довідник / [Вид. 2-ге, доповн.]. Львів: Ладекс, 2009. 84 с.

9. Жаровська О. Паломницькі святині. Львів: Свічадо, 2009. 174 с.

10. Зінько Ю., Мамчур 3., Рутинський М. Сакрально-релігійні ландшафти Західної України // Krajobraz sakralny: Сакральний ландшафт / [pod red. ks. prof. dr hab. Maciej Ostrowski i dr Józef Partyka]. Kraków-Lwów, 2014. C. 85-94. 
11. Костащук I. I. Релігійний простір України: суспільно-географічне дослідження: монографія. Чернівці: ЧНУ, 2018. 512 с.

12. Любічева О.О., Романчук С.П. Паломництво та релігійний туризм: навч. посібник. К.: Альтерпрес, 2011. $416 \mathrm{c}$.

13. Львівська Архідієцезія Римо-Католицької Церкви в Україні.

URL: http://www.rkc.lviv.ua/index.php?lang=1

14. Мороз В. Божа гора - святиня в тіні Почаєва.

URL: http://risu.org.ua/ua/relig_tourism/religious_region/33808

15. Назарук М., Гринчишин T. Сакральні об'єкти в геопросторі сучасного Львова // Krajobraz sakralny: Сакральний ландшафт / [pod red. ks. prof. dr hab. Maciej Ostrowski i dr Józef Partyka]. Kraków-Lwów, 2014. C. 73-84.

16. Паломницькі об’єкти: мапа-путівник / Патріарший паломницький центр Української Греко-Католицької Церкви. Київ, 2011. 171 с.

17. Паломницький центр Матері Божої Неустанної Помочі.

URL: http://www.palomnyk.info

18. Патійчук В. Класифікація релігійно-паломницьких турів за різноякісними ознаками // Наук. вісн. Східноєвроп. нац. ун-ту ім. Лесі Українки. Серія: Географічні науки. Луцьк: Вежа-Друк, 2015. № 14(315). С. 36-48.

19. Патійчук В. О., Якубович Р. П. Проблеми розвитку православного паломництва на теренах Волинської області // Актуальні проблеми країнознавчої науки: матеріали IV Міжнар. наук.-практ. Інтернет-конференції (м. Луцьк, 15-16 листопада 2016 р.) / за ред. В. Й. Лажніка. Луцьк: Вежа-Друк, 2016. С. 127-134.

20. Попович Я. М. Феномен паломництва в католицизмі: дис. ... к-та філософ. наук: 09.00.11 / Я. М. Попович; Житомирський держ. ун-т ім. Івана Франка. Житомир, 2015. $218 \mathrm{c}$.

21. Релігійні організації в Україні (станом на 1 січня 2019 р.) / РІСУ: Релігійноінформаційна служба України.

URL: https://risu.org.ua/ua/index/resourses/statistics/ukr_2019/75410

22. Релігійні тури / Туроператор Оксамит-КЛ.

URL: https://oksamyt-kl.com.ua/excursions/religion

23. Релігійний туризм: термінологічний словник-досвідник / ред. Т. Божук. Львів: Украінський бестселер, 2010. 152 с.

24. Релігійний туризм / РІСУ: Релігійно-інформаційна служба України.

URL: https://risu.org.ua/ua/relig_tourism

25. Релігія і церква в українському суспільстві: результати соціологічного дослідження. URL: http://razumkov.org.ua/uploads/socio/kharkiv_2020.pdf

26. Рожко В. Нарис історії української православної церкви на Волині: Історично-краєзнавчий нарис. Луцьк: Медіа, 2001. 672 с.

27. Свята гора - місце, що зближає нас із Богом / Львівська єпархія ПЦУ. URL: https://uaoc.lviv.ua/parafiji/monastir-polozhennja-rizi-dm

28. Свято-Успенська Почаївська Лавра. URL: http://www.pochaev.org.ua/?pid=1472

29. Свято-Георгіївський чоловічий монстир на Козацьких Могилах. URL: http://georgmonastyr.rv.ua/heorhijivskyj-prydil/

30. Хостел "Пілігрим" при парафії Української Греко-Католицької Церкви. URL: http://www.pilgrim-hostel.com/ 
31. Цілющі джерела Західної України. URL: http://simya.com.ua/tsilyushhi-dzherelazahidnoyi-ukrayiny

32. Чередниченко A. O. Розвиток релігійного туризму як шлях до відновлення туристичної галузі в умовах соціально-економічної кризи // Вісник економіки транспорту і промисловості. № 58. 2017. С. 226-232.

33. Шпарага T., Михалюк М. Передумови виникнення і сучасний стан хасидського паломництва в Україні. Географія та туризм. 2012. Вип. 22. С. 98-105.

\section{REFERENCES}

1. Jackowski, A. (1998). Pielgrzymowanie. Wydawnictwo Dolnoslaskie, 312 pp. (in Polish).

2. Ostrowski, M. (2008). Teologia turystyki. In R. Winiarski (Ed.), Turystyka w naukach humanistycznych (pp. 102-116). Warszawa, Wydawnictwo naukowe PWN (in Polish).

3. Robinson, M. (1998). Sacred Places, Pilgrim Paths: An Anthology of Pilgrimage Paperback. Zondervan, $224 \mathrm{pp}$.

4. Różycki, P. (2016). Turystyka a pielgrzymowanie. Wydawnictwo Wam, 352+16 pp. (in Polish).

5. Schematyzm duchowieństwa i parafii Archidiecezji Lwowskiej Obrządku Lacińskiego (2016). Lwów, 72-74 (in Polish).

6. Kovalchuk, A., Rutynskyi, M., Manko, A., Zavadovskyi, T., \& Kadnichanskyi, D. (2016). Geografiya religijnoho turyzmu v Ukraini. Lviv, 474 pp. (in Ukrainian).

7. Horodyskyi, Yu. (2014). Terytorialni osoblyvosti rozvytku palomnytstva u Lvivskiy oblasti. Visnyk of V. N. Karazin Kharkiv National University, series "Geology. Geography. Ecology”, 41, 101-106 (in Ukrainian).

8. Hrynchyshyn, T. (2009). Lviv sakralnyy: relihiyni obyekty na mapi mista. Atlas-dovidnyk. Lviv, Ladeks, 84 pp. (in Ukrainian).

9. Zharovska, O. Palomnytski sviatyni. Lviv, Svichado, 174 pp. (in Ukrainian).

10. Zinko, Yu., Mamchur, Z., \& Rutynskyi, M. (2014). Religious landscape of western Ukraine. In M. Ostrowski \& J. Partyka (Eds.). Krajobraz sakralny (pp. 85-94), KrakówLwów (in Ukrainian \& Polish).

11. Kostashchuk, I. (2018). Religiynyi prostir Ukrainy: suspilno-geografichne doslidzhennia. Chernivtsi, ChNU, 512 pp. (in Ukrainian).

12. Liubitseva, O., \& Romanchuk, C. (2011). Palomnytstvo ta religiynyi turyzm. Kyiv, Alterpres, $416 \mathrm{pp}$. (in Ukrainian).

13. The Archdiocese of Lviv of the Latins (2019).

Retrieved from http://www.rkc.lviv.ua/index.php?lang=1 (in Ukrainian).

14. Moroz, V. (2019). Bozha gora - sviatynia u tini Pochayeva. Retrieved from http://risu.org.ua/ua/relig_tourism/religious_region/33808 (in Ukrainian).

15. Nazaruk, M., \& Hrynchyshyn, T. (2014). Sakral objects in the geospace of contempotary Lviv. In M. Ostrowski \& J. Partyka (Eds.). Krajobraz sakralny (pp. 73-84), Kraków-Lwów (in Ukrainian \& Polish).

16. Patriarshyy palomnytskyy centr Ukrayinskoyi Hreko-Katolytskoyi Tserkvy. (2011). Palomnytski obyekty: mapa-putivnyk. Kyiv, 171 pp. (in Ukrainian).

17. Palomnytskyi tsentr Materi Bozhoyi Neustannoyi Pomochi. (2019). Retrieved from http://www.palomnyk.info (in Ukrainian). 
18. Patiychuk, V. (2015). Klasyfikatsiya religiyno-palomnytskych turiv za riznoyakisnymy oznakamy. Naukovy Visnyk of Lesya Ukrainka Eastern-European National University, series "Geography sciense", 14(315), 36-48 (in Ukrainian).

19. Patiychuk, V., \& Yakubovych, R. (2016). Problemy rozvytku pravoslavnoho palomnytstva na terenach Volynskoyi oblasti. In V. Lazhnik (Ed.), Aktualni problemy krayinoznavchoyi nauky (pp. 127-134). Lutsk, Vezha-Druk (in Ukrainian).

20. Popovych, Ya. (2015). Fenomen palomnytstva v katolytsyzmi. Zhytomyr, Zhytomyrskyi derzhavnyi universytet imeni Ivana Franka, 218 pp. (in Ukrainian).

21. RISU: Relihiyno-informatsiyna sluzhba Ukrayiny. (2019). Relihiyni orhanizatsiyi $v$ Ukrayini (as of January 1, 2019).

Retrieved from https://risu.org.ua/ua/index/resourses/statistics/ukr_2019/ 75410 (in Ukrainian).

22. Turoperator Oksamyt-KL. (2019). Religiyni tury. Retrieved from https://oksamytkl.com.ua/excursions/religion (in Ukrainian).

23. Bozhuk, T. (Ed.). (2010). Religiynyi turyzm: terminologichnyi slovnyk-dovidnyk. Lviv, Ukrainskyi bestseler, 152 pp. (in Ukrainian).

24. RISU: Relihiyno-informatsiyna sluzhba Ukrayiny. (2019). Relihiynyi turyzm. Retrieved from https://risu.org.ua/ua/relig_tourism (in Ukrainian).

25. Razumkov centr. (2019). Relihiya $i$ tserkva v ukrayinskomu suspilstvi: rezultaty sotsiolohichnoho doslidzhennia.

Retrieved from http://razumkov.org.ua/uploads/socio/kharkiv_2020.pdf (in Ukrainian)

26. Rozhko, V. (2001). Narys istoriyi ukrayinskoyi pravoslavnoyi tserkvy na Volyni: Istorychno-krayeznavchyi narys. Lutsk: Media, 672 pp. (in Ukrainian).

27. Lvivska Yeparkhiya PTsU. (2019). Sviata hora - mistse, shcho zblyzhaye nas iz Bogom. Retrieved from https://uaoc.lviv.ua/parafiji/monastir-polozhennja-rizi-dm (in Ukrainian).

28. Sviato-Uspenska Pochayivska Lavra. (2019).

Retrieved from http://www.pochaev.org.ua/?pid=1472 (in Ukrainian).

29. Sviato-Heorhiyivskyi cholovichyi monastyr na Kozatskykh Mohylakh. (2019). Retrieved from http://georg-monastyr.rv.ua/heorhijivskyj-prydil/ (in Ukrainian).

30. Hostel "Piligrym" pry parafiyi Ukrayinskoyi Hreko-Katolytskoyi Tserkvy Svv. Petra $i$ Pavla. (2019). Retrieved from http://www.pilgrim-hostel.com/ (in Ukrainian).

31. Tsiliushchi dzherela Zachidnoyi Ukrainy. (2019).

Retrieved from http://simya.com.ua/tsilyushhi-dzherela-zahidnoyi-ukrayiny/ (in Ukrainian).

32. Cherednychenko, A. (2017). Rozvytok religiynoho turyzmu yak shliakh do vidnovlennia turystychnoyi galuzi v umovach sotsialno-ekonomichnoyi kryzy. The bulletin of transport and industry economics, 58, 226-232 (in Ukrainian).

33. Shparaga, T., \& Mykhaliuk, M. (2012). Peredumovy vynyknennia i suchasnyi stan khasydskogo palomnytstva v Ukrayini. Geografiya ta turyzm, 22, 98-105 (in Ukrainian).

Стаття: надійшла до редакиї 15.09.2019

доопрацьована 31.10.2019

прийнята до друку 29.11.2019 


\title{
РЕЛІГІЙНО-ПАЛОМНИЦЬКИЙ ТУРИЗМ НА ЗАХОДІ УКРАЇНИ: ОСНОВНІ ЦЕНТРИ І СВЯТИНІ
}

\author{
Юрій Зінько ${ }^{1}$ Марта Мальська ${ }^{1}$, Тарас Гринчишин ${ }^{2}$ \\ ${ }^{1}$ Львівський національний університет імені Івана Франка, \\ вул. П. Дорошенка, 41, 79007, м. Львів, Украӥна, \\ e-mail: zinkoyuriy@gmail.com,malskym@ukr.net, \\ 2 Львівська обласна державна адміністрачія, \\ вул. В. Винниченка, 14, 79008, м. Львів, Україна \\ e-mail: tarasiy4@gmail.com
}

Проаналізовано чинники формування й основні центри та святині паломництва та релігійного туризму у Західному регіоні України. Подано структуру релігійного простору 8 областей заходу України в розрізі основних християнських конфесій. За останніми статистичними даними на заході України серед християнських конфесій маємо домінування вірян і громад Української Грекокатолицької церкви, Православної церкви України, Української православної церкви Московського патріархату та Римо-католицької церкви.

Схарактеризовано головні паломницькі центри, які репрезентують християнські конфесії регіону, приваблюючи їхніх вірних, та водночас виконують функції центрів релігійного туризму для ширшого кола осіб. Серед таких слід, зокрема, виділити: Унівську лавру, Крехівський і Гошівський монастирі, Марійський духовний центр у Зарваниці (Греко-католицька церква); Манявський скит, Монастир св. Георгія на Козацьких могилах (Православна церква України); Почаївську лавру, Зимненський і Межиріцький монастирі, монастирі Буковини та Закарпаття (Православна церква Московського патріархату). Водночас Римо-католицька церква представлена санктуаріями: базилікою Успіння Пресвятої Діви Марії у Львові, костелами в Стрию, Більшівцях, Чорткові, Летичеві та інших населених пунктах. Щорічна кількість відвідувачів згаданих основних центрів становить від 30 до 100 тисяч осіб на рік.

Щодо нехристиянських релігій, то в регіоні залишились важливі святині для хасидських паломників у Белзі, Меджибожі та інших містах.

Водночас важливими дестинаціями виступають низка обласних центрів. У Львові, Івано-Франківську, Луцьку, Тернополі є багато храмів, що з огляду на наявність об'єктів релігійного культу та значну архітектурну привабливість виконують як паломницьку, так релігійно-туристичну функцію.

Важливою складовою паломницько-туристського руху на заході України часто виступають релігійні святині, що мають первинно природнє походження. Серед них місця появи Богородиці, приурочені до окремих пагорбів чи джерел, а також давні печерні монастирі. Їх активному відвідуванню вірянами і туристами активно сприяють численні паломницькі агенції та туристичні фірми.

Розвиток релігійних та паломницьких центрів пов'язаний з розвитком інфраструктури обслуговування, сервісних комплексів та мережі закладів розміщення різного типу. Рекомендовано організовувати освітні та наукові заходи екуменічного характеру та зустрічі вірних різних конфесій у відомих релігійних центрах регіону.

Ключові слова: паломництво, релігійний туризм, конфесії, храм, святиня, паломницький центр, інфраструктура. 